\author{
Magdalena Mikołajczyk \\ Uniwersytet Pedagogiczny w Krakowie
}

\title{
Niektóre pojęcia i słowa klucze teorii krytycznej
}

\section{Some Concepts and Keywords of Critical Theory}

\begin{abstract}
The subject of the analysis is the conceptual network used by researchers identified with the critical paradigm or theory. The source is provided by glossaries presenting characters, problems and controversies. Studies of this type contain a selected set of terms, reporting definitions and hence methods of understanding social phenomena that are proprietary or - less frequently - agreed within a scientific field. The analysed materials provide an illustration of the interdisciplinary and multi-faceted nature of the critical approach. They also show the importance of the attainments of certain authors also as regards creativity in word formation and the ability to explicate notions and their accompanying concepts. Terminologies often determine the status of a scientific theory. In turn, the constructs of notions are a confirmation of the correctness of observations and social imagination. Notions themselves, on the other hand, may be compared to leads picked up by successive generations enabling the opening of new gates and the setting of new paths. The term "rhisomatic" referred to texts and discourses by French philosophers (Félix Guattari, Gilles Deleuze) may also illustrate the formation of critical theory. If political sciences were to use the attainments of critical social sciences to date, it is worthwhile to take a look at the political contexts of the research done to date in this area and the specificity of the methodological approach, including the construct of conceptual network.
\end{abstract}

Keywords: interdisciplinary approach, critical theory, conceptual network, key problems, creation of notions

Na samym dole, na czubku korzenia, tkwi strach przed ciemnością i zimnem.

A kiedy nadamy ciemności jakąś nazwę, zyskujemy nad nią pewną kontrolę.

Przynajmniej myślimy, że zyskujemy, co jest niemal tak samo ważne.

Pragnienie tworzenia struktur jest silne jak zawsze, nawet dzisiaj, wśród błyskotliwych i inteligentnych nas, którzy wiemy o teflonie i centralnym ogrzewaniu. 
Przedmiotem analizy są - należy to zastrzec - niektóre sposoby przedstawiania teorii krytycznej, identyfikowania postaci twórców i ich poglądów na ważne społeczne problemy, a także cele, jakie może stawiać sobie naukowiec. Trudno dokonać pełnego przeglądu nurtów, przedstawicieli, inspiracji, a następnie recepcji nawet najważniejszych prac, można natomiast skonstatować rozrastanie się i podejmowane próby systematyzowania właściwej dla tego swoistego paradygmatu siatki pojęciowej ${ }^{1}$. Językowa wrażliwość, wyczulenie na niuanse, które muszą się pojawiać, by opis społeczeństwa odpowiadał skomplikowanej naturze desygnatu i pozwalał przedstawić spetryfikowane dzięki kulturze struktury, instytucje, sposoby zachowań, a także wszelkie ich dialektyczne zależności, były i są udziałem współtworzących krytyczne podejście badawcze. Trudno przesądzić lub zmierzyć inwencję w tworzeniu terminologii, wyobraźnię, której ostatecznym skutkiem byłoby redefiniowanie pojęć występujących potocznie lub doprecyzowanych na użytek naukowy czy stworzenie takich definicji projektujących, które zmieniłoby przynajmniej sposób postrzegania faktów społecznych. W pewnym sensie musi to być analiza prowadzonej w kręgu współtwórców krytycznego paradygmatu introspekcji, zwłaszcza że można ryzykować tezę, iż zainteresowania tego rodzaju podejściem badawczym podzielają częściej myślący podobnie, lokujący się może nie na biegunach, ale w podobnych miejscach, kontinuów wyznaczanych przez naturalizmantynaturalizm, pozytywizm-konstruktywizm, realizm-relatywizm, obiektywizm-podejście uznające niezbędność wartościowania. Dodać można kolejne: idealizm-materializm, myślenie linearne-binarne, metafizyka-dialektyka.

Przedstawiciele nauk humanistycznych i społecznych, naukowcy i pozostali intelektualiści, to znaczy niekoniecznie występujący w akademickich barwach (publicyści i wszelcy komentatorzy współczesnych procesów społecznych), podlegają naciskom charakterystycznym dla właściwych w ich sytuacji kontekstów od historycznego i geograficznego do społecznego (strukturalnego, statusowego, normatywnego, o ekonomicznym nie zapominając). Rzecz można by traktować jako truizm, w dodatku skutkujący koniecznością pomieszania wielu możliwych teoretycznych wątków, gdyby nie wzgląd na toczącą się, właściwie równolegle

Paradygmat traktuję tu jako zakorzeniony w kulturze i powszechnie przyjęty (akceptowany społecznie, uznany i podtrzymywany normatywnie) sposób myślenia determinujący zainteresowania, postrzeganie i sposoby interpretacji, nieuniwersalny (choć pretendujący do uniwersalności), właściwy jednak swoim czasom. Zatem sposób myślenia dający się przełamywać, weryfikować, zastępować innym. Czasem także stanowiący ograniczenie, w nauce wynikające przykładowo z bezdyskusyjnego stosowania takich, a nie innych metod, procedur badawczych. Im bardziej otwarte pozostaje pole wyboru dla wyobraźni, intuicji, motywowanych niekomercjalnie poszukiwań naukowych i im mniej wyznaczonych, traktowanych naturalnie obowiązków, tym bardziej rola paradygmatu staje się ograniczona. 
do rozwoju wspomnianych nauk, debatę nad zasadnością i możliwością zachowania obiektywizmu w procesie badawczym, nad postawą neutralności lub zaangażowania badacza, dalej zaś nad jego uczestnictwem lub możliwością interwencji. Paradygmat krytyczny oraz wszelkie dyscypliny w ujęciu radykalnym (np. krytyczna pedagogika, krytyczne nauki o zarządzaniu, socjologia radykalna i krytyczna²) podkreślać będą konieczność precyzyjnego uzgodnienia roli badacza i roli obywatela. Nierzadko także innych jeszcze tożsamości, ważnych dla współczesnego społeczeństwa i każdego $\mathrm{z}$ nas z osobna. Społeczna funkcja filozofii, o której pisał Max Horkheimer, rozciąga się na inne dyscypliny. Warto przypomnieć, że identyfikowana była właśnie z krytyką stanu obecnego:

Nie oznacza to gderania na poszczególne idee czy stosunki, jakby filozof był komicznym dziwakiem, ani też narzekania na tę czy inną, wyizolowaną okoliczność, i zalecania środków zaradczych. Głównym celem tej krytyki jest niedopuszczenie do zagubienia się ludzi w ideach i sposobach postępowania, jakie oferuje społeczeństwo w jego obecnej formie (Horkheimer, 1987, s. 235).

Równie ważny jest postulat rozumienia kontekstu, w którym się działa, kredowego koła tworzonego przez epokę, kulturę, język, dominujące i zrytualizowane wzory zachowań, ideologię. Przedmiotem badania jest więc, parafrazując, historia, którą tworzą ludzie, ale nie dowolnie, tylko w takich okolicznościach, w jakich się znaleźli. Celem nauki/teorii jest nie tylko wyjaśnianie, ale praktyka sięgająca niejako przedmiotu badanego. Nie bez znaczenia jest też kolejna jej funkcja - normatywna.

Dla autorów w sposób świadomy nawiązujących do tradycji szkoły frankfurckiej lub takich, których prace są w nurt krytyczny włączane ze względu na ukierunkowane zainteresowania (przedmiot badań) czy preferowany rodzaj metodologii (źródeł i ich krytyki, wnioskowania, interpretacji) powyższe stanowi differentia specifica. Podobnie skądinąd jak orientacja poznawcza na różne, zgoła całkiem odmienne, rodzaje społecznych obiektów, pozostające w dialektycznym niejako związku - makrostruktury i osobowości - determinanty działania gospodarki globalnej oraz kompleksy jednostek, mechanizmy rzutujące na kondycję podmiotów takich jak państwa, ale też wyznaczające pole działania reprezentan-

Michael Burawoy postulujący reorientację nauk społecznych, orędujący za socjologią publiczną, omawiając „podział pracy socjologicznej”, ukierunkowanie socjologii na publiczność akademicką i pozaakademicką, nurt krytyczny identyfikował $\mathrm{z}$ wiedzą refleksyjną i dwoma pytaniami de facto odnoszącymi się nie tylko do tej dyscypliny naukowej: „dla kogo?”, „po co?”. Socjologia w dotychczasowym kształcie wyróżniała się m.in. zwracaniem uwagi na społeczny konsensus i ignorowaniem opresji doświadczanej przez wiele grup społecznych (Burawoy, 2009, s. 535-536). 
tów różnych kategorii społecznych, grup, subkultur. Dodajmy, że szczególną uwagą objęte są tu wszelkie formy asymetrii, opresji, wykluczenia, a troską - aspiracje emancypacyjne. Naciski płynące $z$ otoczenia równoważone są przez wolę i dający się kształtować ład normatywny. W obrębie krytycznego paradygmatu poruszać się będą zainteresowani uwikłaniem w historię i kulturę, etnicznością i rasą, uwikłaniem wynikającym $\mathrm{z}$ takiego a nie innego sposobu produkcji (co oznacza różne usytuowanie w procesie pracy, różne statusy, słowem różnice klasowe), uwikłaniem w płeć. Włączane będą w ten nurt zróżnicowane studia nad polityką tożsamości, polityką różnicy, ale także teoria zależności i studia postkolonialne.

Nie ograniczając się tutaj jedynie do prezentacji, rzeczywiście rozproszonego w czasie i na kontynentach, zbioru uczonych (nazwa szkoły jest bowiem relatywnie często kwestionowana, zastrzegana tylko dla epizodu frankfurckiego [Szacki, 2007, s. 523; Wycisk, 2014, s. 232], lub odwrotnie - przez dialogujących z oponentami współtwórców postrzegana jest jako możliwa ostatnia $\mathrm{z}$ tego typu naukowych formacji [Adorno, 1984 , s. 45]), postaram się wyodrębnić kilka terminów stosowanych w obrębie teorii krytycznej, jednocześnie ją określających.

Teoria krytyczna traktowana jest (przez jej badaczy, w mniejszym lub większym stopniu zgodnych z proponowanymi w tym nurcie założeniami) jako jeden z wariantów (lub przyczynków) teorii społecznej, w niektórych przypadkach prawie że identyfikowalnej z teorią społeczną (Elliott, 2011, passim) ${ }^{3}$. Charakterystyczne jest też akcentowanie przekonania o istnieniu hierarchii ważności problemów społecznych, o konieczności zwrócenia uwagi na przyczyny napięć i konfliktów, konieczności rozróżnienia strukturalnych nacisków i niezamierzonych konsekwencji działań ludzkich. Wszystko to rzutuje na postawę badacza (Mucha, 1986, s. 171). Wymogiem poznawczym w tym nurcie pozostaje wyostrzenie wrażliwości, rozumienie dwoistej istoty społeczeństwa (przedmiotu badanego i podmiotu określającego m.in. sytuację badającego), historii ludzkości wyrastającej $\mathrm{z}$ historii naturalnej, podobnie lub w inny sposób nieprzewidywalnej (Adorno 1984, s. 6, 17). Teorii krytycznej - z której tradycjami najczęściej

Wgląd w układ rozdziałów przytaczanej publikacji oraz porównanie struktury pracy z zawartością treści słowników teorii krytycznej pozwala wykazać znaczne podobieństwo. Trudno jednak wskazać decydujące o takiej analogii przesłanki. Czy to Anthony Elliott, chcąc pokazać nurty właściwe współczesnym naukom społecznym, rozpoczyna od przedstawienia szkoły frankfurckiej, a następnie kontynuuje, prezentując korespondujące z nią koncepcje autorskie i teorie (strukturalizm i poststrukturalizm, teorie strukturacji, współczesna teoria krytyczna, teoria feministyczna i postfeministyczna, postmodernizm, teorie sieci i teorie globalizacji), czy autorzy analizowanych słowników tak właśnie widzą teorię krytyczną i uznają za konieczne do jej rozumienia odwołanie się do większości wymienianych nurtów (ze zdecydowanie oszczędniejszym wglądem w koncepcje postnowoczesności Manuela Castellsa, Zygmunta Baumana, oraz z dostrzegalną dysproporcją wątków ekonomicznych, także dotyczących globalizacji)? 
będziemy wiązać studia nad kulturą i badania stosunków społecznych - nie sposób zrozumieć bez minimalnego przygotowania filozoficznego. $\mathrm{W}$ badaniach politologicznych można $\mathrm{z}$ kolei czerpać inspirację na przykład z właściwego dla krytycznych socjologów sposobu przedstawiania relacji interpersonalnych i grupowych, charakterystycznego opisu funkcjonowania instytucji społecznych (ich hierarchiczności, funkcji i dysfunkcji), reprezentacji odniesionej do interesów, skądinąd pozostających w związku ze strukturą społeczną (niekoniecznie uświadamianych, niekoniecznie determinujących zachowania polityczne).

Przy konstatacji i jednocześnie niewzbudzającym kontrowersji uznaniu, że politologia jest nauką wieloparadygmatyczną (Klementewicz, 2010, s. 57-81; 2013a, s. 164-198; 2013b, s. 31-43), można traktować teorię krytyczną jako jeden ze sposobów myślenia, wyznacznik tematyki i jakościowych, głównie interpretatywnych, metod badania. Wobec równie złożonych właściwości polityki, analogicznie do złożoności procesów i struktur społecznych, proponuje ona nieufność i ostrożność, bez arogancji właściwej prognozującym wynalezienie kamienia filozoficznego. Jest $\mathrm{w}$ większym stopniu wariantem założeń badawczych niż konsensusem co do istotnych właściwości polityki (Karwat, 2011, s. 76). $\mathrm{Z}$ jednym wyjątkiem, ponieważ oprócz zjawisk ważnych dla rozumienia polityki (tzn. sprzeczności interesów, dystrybucji i legitymacji władzy, funkcjonowania państwa, złożonych okoliczności determinujących procesy polityczne, motywacji decyzji i działań politycznych, komunikacji politycznej i in.) niezmiernie ważnym przedmiotem zainteresowań są ideologie. Ich/jej (polityki) znaczenie jest eksponowane w teorii krytycznej, a twórcy takich pojęć, jak hegemonia kulturowa, przemoc symboliczna, wspólnota komunikacyjna, wspólnota interpretacyjna, kolektyw i styl myślowy, wymieniani są wśród intelektualistów, których obraz/krytykę społeczeństwa warto mieć na uwadze. W centrum zainteresowań pozostaje proces tworzenia i akceptowania przez różne zbiorowości (kategorie społeczne, grupy) takiego porządku normatywnego, instytucjonalnego, który bynajmniej nie odpowiada ich interesom, tworzy jednak złudne przekonania o bezalternatywnej prawomocności. Jako trafne (choć dyskusyjne jest, czy wyłącznie w odniesieniu do frankfurckiego okresu działania Instytutu Badań Społecznych) można uznać wyróżniki wymienione przez Filipa Pierzchalskiego - metateoretyczny status teorii krytycznej, preferencje dla dialektycznego poznania i ujawniania struktur głębokich, preferencje dla hermeneutyki, a także antyscjentyzm i aksjologiczne nacechowanie (Pierzchalski, 2017, s. 20-21). Trudno nie dodać, że w klasyfikacji na politologiczne sekty - uwzględniającej kryteria ideologiczne i metodologiczne, dokonywanej żartobliwie przez Gabriela Almonda pod koniec lat 80. XX wieku - reprezentanci (przynajmniej ówcześni) teorii krytycznej lokowaliby się po stronie „miękkiej lewicy” (za: Porębski, 2013, s. 104). Marksowska proweniencja, krytyczne i pesymistyczne nastawienie 
do „ideologicznych aparatów państwowych”, kosmopolityzm i postulaty uwłasnowolnienia różnych podmiotów, o których prawach lub autonomii niechętnie się dyskutuje (tym mniej chętnie, im bardziej tradycjonalna jest kultura polityczna i im bardziej autorytarny jest system polityczny) - wszystko to może powodować zepchnięcie teorii krytycznej w narożnik, na margines. Paradoksalnie jednak jest to miejsce szczególnie ciekawe dla krytycznie zorientowanych badaczy. Mowa tu oczywiście o próbach wywodzących się z ideologicznych przesłanek dyskredytowania niekiedy skomplikowanych i żmudnych badań z racji ich interpretatywnego charakteru i demaskacyjnych zapędów (nie anarchistycznych, ale z pewnością antytotalistycznych). Dostrzegalna jest także praktyka omawiania koncepcji autorskich bez prezentacji wyjściowych założeń, bardzo przydatna $\mathrm{w}$ marginalizowaniu roli krytycznego paradygmatu (co występuje w politologii, zwłaszcza rodzimej ${ }^{4}$ ) lub traktowania go jako wąskiego podtypu teorii normatywnych (von Beyme, 2005; Buckler, 2006, s. 181-186).

Jedną z ciekawych okoliczności jest to, że teoria krytyczna, w odróżnieniu od innych, alternatywnych, równie mocno lub mocniej niż ona zakorzenionych w naukowej tradycji paradygmatów, podejść badawczych czy wielowątkowych koncepcji, doczekała się opracowań źródłowych o charakterze informacyjno-syntetycznym, to znaczy leksykonów i słowników. W amerykańskiej i brytyjskiej literaturze naukowej jest ich kilka, w tym niektóre branżowe, odnoszone do zastosowania w takich dyscyplinach, jak nauki o zarządzaniu, pedagogika, teoria literatury. Dla porównania nie ma analogicznych słowników rekonstruujących terminologię właściwą dla klasycznych teorii społecznych, takich jak funkcjonalizm, teoria konfliktu, teoria wymiany lub interakcjonizm symboliczny, czy podobnych opracowań poświęconych behawioralizmowi, instytucjonalizmowi, teorii racjonalnego wyboru. Spośród licznych opracowań prezentujących kluczowe pojęcia i kwestie istotne dla dyscyplin naukowych z szeroko rozumianej humanistyki i nauk społecznych (filozofii i jej działów, socjologii, psychologii, ekonomii i in.) lub systematyzujących wiedzę o dowolnej aktywności człowieka (pomoc społeczna, praca, wychowanie, także komunikacja i wszelkie formy sztuki) te, których przedmiotem jest teoria krytyczna, mogą stanowić reprezentację nauk o kulturze (kulturoznawstwa) . Część autorów łączy oba podejścia,

\footnotetext{
Wgląd w bibliografię prac politologicznych, publikowaną jeszcze do niedawna w periodyku „Athenaeum. Polskie Studia Politologiczne”, lub w publikacje rejestrowane w Polskiej Bibliografii Naukowej pokazuje procentowo niewielkie zainteresowanie teorią polityki w ogóle, incydentalne (głównie związane z recepcją prac J. Habermasa) zainteresowanie studiami krytycznymi. Być może pierwszą jaskółką zmiany tej sytuacji jest poświęcony paradygmatowi krytycznemu obecny numer „Teorii Polityki”.

Analizowano pięć publikacji zawierających w tytule „słownik” lub „słowa kluczowe” teorii krytycznej (Orr, 1991; Macey, 2000; Buchanan, 2010; Payne, Barbera, 2010; Felluga, 2015).
} 
pokazując już w tytule możliwą symbiozę (Payne, Barbera, 2010). Wgląd w samą strukturę tego typu publikacji pokazuje, że im bardziej usystematyzowane podejście, tym łatwiej skonstruować podręcznikowy przekaz, narrację o stosowanych metodach, prowadzonych badaniach, osiągniętych rezultatach, łatwiej eksplikować - jeśli można tak powiedzieć - cały paradygmat lub teorię. Wyzwanie stanowią prezentacja podejścia o pluralnych tradycjach, różno- i wielopokoleniowych zespołach badawczych realizujących rozrzucone tematycznie projekty, czy też uporządkowanie stosowanych kategorii pojęciowych, metodologicznych założeń, rygorów determinujących badawcze procedury kreatywnego bricolage’u.

Dla teorii (zarówno społecznych, jak i politycznych) terminologiczna precyzja jest czymś wysoce pożądanym i jednocześnie trudnym do osiągnięcia. Skutek wysiłków może być odmienny od zamierzonego. I nie chodzi tu o samo współwystępowanie pojęć w języku potocznym i naukowym, podobne funkcje pełnione są przez język poezji, nauki i mistyki (Ossowski, 1983, s. 228-231). Zdolność do porozumienia się może determinować powstanie wąskiej, ekskluzywnej, zamkniętej grupy odbiorców, i wielu twórców spod omawianego znaku ta, niekoniecznie projektowana, niedogodność dopadła. Stanisław Ossowski jako przykład wszelkich niedoskonałości języka nauk społecznych przytaczał historię o pracowniku naukowym posługującym się terminami freudowskimi ( $\mathrm{id}$, ego, superego) bez rozumienia ich znaczenia, za to z entuzjazmem i dość elastycznie (Ossowski, 1983, s. 235). Słowniki, o których mowa, z pewnością mogą odgrywać, wobec powyższego, prewencyjną rolę. Ukierunkowanie lub deklarowanie przez badacza określonego typu wartości nie przesądza natomiast o udziale perswazji czy językowych manipulacji w opisie społecznej rzeczywistości. Dla współtwórców krytycznego podejścia (a wśród nich jest liczne grono teoretyków literatury, krytyków literackich i filmowych, językoznawców) wykorzystanie języka (możliwych do przekazania werbalnie i wizualnie emocji) do stworzenia obrazu rzeczywistości zgodnego z interesem nadawców czy ich patronów jest czymś oczywistym, technologią intelektu (Marody, 1987, s. 257), stanowiącą często przedmiot bardziej złożonych studiów. Język naukowy zawiera terminy empiryczne, odnoszące się do obserwowanej rzeczywistości, umożliwiające jej opis. Terminy teoretyczne nie działają na zmysły w oczywisty sposób, pozwalają jednak dotrzeć do tego, co przed doświadczeniem ukryte „w głębszej warstwie rzeczywistości” (Krauz-Mozer, 2005, s. 72). Przy całej multidyscyplinarnej palecie zainteresowań wiążących się z teorią krytyczną relatywnie ubogo będzie się prezentował katalog pojęć odnoszących się do polityki sensu stricto, co nie znaczy, że prezentowane jako charakterystyczne dla tego nurtu pojęcia nie są przydatne dla politologa. Wśród pojęć możemy wyróżnić: (a) wspólne naukom społecznym; (b) wspólne naukom politycznym, typowe dla dyscypliny; (c) typowe dla danej szkoły, kierunku czy teorii; oraz (d) używane przez badaczy w określo- 
ny sposób (Blok, 1999, s. 34); słowniki teorii krytycznej zawierają ostatnie dwie kategorie tej klasyfikacji.

Zawartość słowników, opracowywana przynajmniej częściowo na podstawie publikacji autorów, których twórczość wiąże się (lub jest przedstawiana jako spójna) z krytycznym paradygmatem, wykazuje coraz większe znaczenie - wraz z upływem czasu, od powstania szkoły frankfurckiej do teraz - pojęć uznawanych za najważniejsze, słów kluczy. Tak rozumiane są pojęcia ogniskujące uwagę, wokół których toczy się dyskusja, oraz - jeszcze inaczej - najtrafniej korelujące z doświadczeniem współczesności rozumianej jako pełen splot okoliczności społecznych, gospodarczych, technologicznych, polityczno-prawnych i innych jeszcze, wymagający diagnozy, interpretacji, wyjaśnienia. Oczywiście nie chodzi tu o słowa klucze w rozumieniu stosowanym przez językoznawców, w tym Annę Wierzbicką, uniwersalne, spotykane w każdej z kultur, tych bowiem jest niewiele (Wierzbicka, 2007) ${ }^{6}$. Tym bardziej o tagi lub hashtagi, specyficzne znaczniki służące do wyszukiwania informacji w mediach społecznościowych. Moda na zwięzłe, skrótowe sygnalizowanie treści nie omija nawet naukowych publikacji. Tu jednak eksplikacja fundamentalnych dla teorii kategorii pojęciowych służy jej poznaniu (nie wyszukiwaniu podobieństw), każdy z przywołanych terminów omawiany jest daleko szerzej niż jego nominalne znaczenie. Jeśli na przykład pierwszym definiowanym terminem jest abject (abjection), to z wielowymiarowym przedstawieniem znaczenia, genezą wywodzoną z psychoanalizy i sensem nadanym przez Julię Kristevą ${ }^{7}$. Filozofowie kultury w tego typu formie (objaśnieniach wybranych kluczowych terminów) starają się niekiedy tłumaczyć bardziej skomplikowane autorskie pomysły (Baudrillard, 2012).

W przypadku teorii krytycznej mogą to być też kluczowe koncepty lub problemy koncentrujące zainteresowania przedstawicieli różnych dyscyplin, generacji lub narodowości ${ }^{8}$. Wskaźnikowe są wieloletnie przedsięwzięcia wydawnicze. Na przykład w serii „Kluczowe kwestie teorii krytycznej” oficyna Humanities Press International wydała od lat 90. XX wieku do teraz publikacje dotyczące socjalizmu, wyzysku, sprawiedliwości, pojęcia rasizmu, alienacji i krytyki społecznej, ekologii, imperializmu, demokracji, płci kulturowej. Nie wyczerpuje to ka-

6 Badania Anny Wierzbickiej, lingwistki, której projekt realizowany w Australii miał się kończyć utworzeniem "naturalnego metajęzyka semantycznego" ( $\mathrm{z}$ ang. natural semantic metalanguage - NSM), pozwoliły wyodrębnić tylko 63 pojęcia uniwersalne (podobno jest jeszcze jedno), obecne w każdym języku, umożliwiające porozumienie międzykulturowe.

$7 \quad$ Według tej bułgarsko-francuskiej intelektualistki abject to coś, co funkcjonuje poza obowiązującym porządkiem symbolicznym. Ten wstręt, obrzydzenie, któremu poświęciła esej, jest pojęciem granicznym, w społecznym sensie implikującym wykluczenie, w doświadczeniu jednostek lub zbiorowości uniemożliwieniem podmiotowości.

8 Wbrew pozorom na kartach anglojęzycznych słowników przywołano badaczy z różnych kontynentów. 
talogu pojęć wartości, dobitnie jednak potwierdza zainteresowania. Z pewnością brakuje przeglądowego studium dotyczącego władzy lub państwa. Przyznać jednak należy, że zarówno w pierwszym pokoleniu frankfurtczyków, jak i w kolejnych generacjach badaczy nawiązujących do ich dorobku, nie było osoby zorientowanej na taki cel badawczy i zmotywowanej do stworzenia i systematycznego wykładu teorii polityki (Wiśniewski, 2004, s. 112). Nie wykluczało to wskazanych zainteresowań, jedność teorii z praktyką miała jednak w rozumieniu tej formacji zupełnie inny sens.

Leksykonowe, zatem siłą rzeczy wyselekcjonowane i lapidarne, prezentacje dorobku przedstawicieli szkoły krytycznej, ich pomysłów i idei, żmudnych niekiedy ustaleń i interpretacji odwołujących się do szerokiego materiału źródłowego, stanowią reprezentację cech krytycznej teorii (paradygmatu) i stojącego za nią intelektualnego środowiska.

Stąd, po pierwsze, apercepcja - pojęcie wymyślone przez Gottfrieda Wilhelma Leibniza dla opisania przez umysł własnego stanu wewnętrznego - rozwijana między innymi przez Kanta (Buchanan, 2010, s. 25), oznaczająca dyspozycję psychiczną do poznawania samego siebie i integracji doświadczeń, antycypację poprzedzającą myśl i słowo, w społecznym zaś sensie uwarunkowaną kulturowo i strukturalnie intuicję. Jeszcze raz warto podkreślić nacisk frankfurtczyków i ich następców na zdeterminowane wieloma kontekstami i dialektyczne przedstawianie zachowań jednostek i sytuacji społecznych, korzystanie z dorobku antropologii kulturowej w określaniu swoistości perspektyw, nierzadko mocny akcent na historyzm. Określając właściwości teorii krytycznej, można dodać, że jest ona (tzn. wywodzący się z tego krytycznego nurtu badacze) samoświadoma, samokrytyczna, bez pretensji do wszechstronności i obiektywizacji w odróżnieniu od innych konkurencyjnych paradygmatów.

Po drugie, niewątpliwie należałoby wskazać pojęcie, niezmiernie ochoczo zaadaptowane w nowszych wersjach słowników, pozwalające na metaforyczne zastosowanie także dla tej charakterystyki. Chodzi tu o rizomatyczność, ten rodzaj nieustrukturyzowanej, za to skomplikowanej, figury, który przypomina system korzeni, kłącze. Nie jest to jedyny termin, którego wprowadzenie w system pojęciowy teorii krytycznej zawdzięczamy pracom Gilles'a Deleuzéa i Félixa Guattariego, użyteczny w tym miejscu dla zobrazowania środowiska wywodzącego się lub włączanego w orbitę wpływów teorii krytycznej. Wskazywany jest pewien trzon oraz rozgałęziające się, splątane, przenikające się tradycje intelektualne, terminologie i przekonania (wśród nich na przykład uprzedzenia do uprzedzeń). Punktem wyjścia są tradycje marksistowskie i freudowskie. Rzutuje to na gwarancję słownikowego miejsca dla Karola Marksa (także, w dużo mniej rozwiniętych hasłach, Fryderyka Engelsa), Györgya Lukácsa, Antonia Gramsciego i Ernsta Blocha, wielu jeszcze innych, w tym na przykład Ágnes 
Heller, frankfurtczyków kilku generacji, autorów krytycznych recepcji tego dorobku, w tym Louisa Althussera, Étienne’a Balibara, kontynuatorów twórczo rozwijających wybrane wątki. W żadnym ze słowników nie zostaną pominięte duety, takie jak Antonio Negri, Michael Hardt czy Ernesto Laclau i Chantal Mouffe. Rozróżnienie może dotyczyć twórców i teoretyków literatury (tu koniecznie Walter Benjamin, Bertolt Brecht, Lucien Goldmann, Pierre Macherey, Terry Eagleton, Fredric Jameson), historyków (Eric Hobsbawm) oraz filozofów (Jean-Paul Sartre, Jacques Derrida, Gilles Deleuze). Omawiany jest marksizm, krytyka marksistowska i marksistowski feminizm. Nie używa się określeń rozróżnienia marksizm i postmarksizm, jakkolwiek poststrukturalizm jest czymś identyfikowalnym. Reprezentacja szkoły krytycznej wymieniona jest w stosownym haśle porządkującym historię Instytutu Badań Społecznych (Macey, 2000, s. 139-140; Payne, Barbera, 2010, s. 284; Buchanan, 2010, s. 180-182). Szereg otwierają Max Horkheimer, Theodor W. Adorno, Herbert Marcuse, Erich Fromm, Leo Löwenthal. Oczywiście rozwinięta jest biografia i komplet pojęć charakteryzujących koncepcje Jürgena Habermasa. Wśród kontynuatorów (nie sukcesorów - takim terminem określa się relację teorii krytycznej z koncepcjami tworzonymi w szkole frankfurckiej) wymieniani są bez względu na rok urodzenia Karl-Otto Apel, Claus Offe, Albrecht Wellner i Axel Honneth. Ten ostatni wpływowy nie tyle z racji kierowania Instytutem Badań Społecznych, ile z teorii uznania traktowanej jako kolejna (lub jedna z możliwych) formuła współczesnej teorii krytycznej, centrum grawitacyjne trzeciego pokolenia teorii krytycznej (Müller, Czerniak, 2012, s. VII). Co ciekawe, zignorowana została postać jednego z założycieli Instytutu Friedricha Pollacka, co tylko potwierdza, że reprezentowane przez niego ekonomiczne zainteresowania zostały przytłumione przez metaforyczny gąszcz publikacji poświęconych psychoanalizie, językoznawstwu i studiom kulturowym. Niedoreprezentacja, nawet w nowszych wersjach słowników, dotyczy współczesnych kontynuatorów wątków ważnych w obszarze krytycznego paradygmatu (przykładem może być Wendy Brown).

Umieszczane $\mathrm{w}$ słownikach noty biograficzne przedstawicieli nurtu krytycznego uzupełnione są o nazwiska tych, którzy zostali uznani za ascendentów tego nurtu teoretycznego. Jest tu szereg filozofów, filozofów społecznych, etyków, historyków (w tym historyków religii i sztuki), antropologów i socjologów, lingwistów i semiologów, kontynuujących wątki freudowskie psychiatrów. Bezsprzecznie jest też pierwsza liga filozofów dostarczających inspiracji - reprezentatywnych dla fenomenologii, szerzej - filozofii języka (od Ludwiga Wittgensteina do Noama Chomsky’ego, poza tym biografie i główne koncepty reprezentantów postmodernizmu, takich jak Jean-François Lyotard, Jacques Derrida, Richard Rorty, Gianni Vattimo). Na przykład, jeśli omawiana jest historia, obowiązkowo przedstawiona zostanie francuska szkoła Annales z liczny- 
mi jej przedstawicielami, głównie jednak pierwszego i drugiego pokolenia. Także dlatego, że odnotowywany jest jej wpływ lub inspiracja dla prowadzonych przez Michela Foucaulta przekrojowych studiów nad szaleństwem czy więzieniami (Macey, 2000, s. 17; Buchanan, 2010, s. 21). Jeśli zaś socjologia, to obowiązkowe jest odniesienie do prac Ervinga Goffmana, Anthony'ego Giddensa, Urlicha Becka, Thorsteina Veblena'.

Podobnie rizomatyczny charakter ma układ związany z diachronią i synchronią wpływów różnych alternatywnych kierunków i szkół. Omawiane są nie tylko prace sygnowane przez frankfurtczyków, ich ideowych i naukowych ojców (a także różnie selekcjonujących ten dorobek spadkobierców). Współwystępują zatem marksizm i psychoanaliza, filozofia nauki, materializm kulturowy, materializm historyczny, strukturalizm i poststrukturalizm, teoria literatury i lingwistyka, postmodernizm i dekonstrukcja. Teoria krytyczna niewątpliwie rozciąga swoje pole wpływu na tyle, że przedstawiane są w jej ramach niektóre teorie globalizacji, studia postkolonialne, badania rasowe i etniczne, feminizm, teoria queer.

Interdyscyplinarność, wielowątkowość, intertekstualność (która też, nawiasem mówiąc, stanowi termin ważny w nurcie badań krytycznoliterackich) nie wyklucza tego, że niektóre pędy metaforycznego kłącza czy drzewa szczególnie obrodziły terminami, dla których niezbędna staje się definicja sprawozdawcza lub wręcz projektująca. W pewnym sensie jest to oczywiste, że niewtajemniczony nie zdekoduje znaczeń pojęć właściwych marksizmowi tu tłumaczonych (tj. wartości dodanej, fałszywej świadomości, stosunków produkcji, utowarowienia, alienacji, imperializmu) i innych, przywoływanych z filozoficznych tradycji, jak na przykład „faktyczność” czy „bycie-w-świecie”, albo jeszcze wyraziściej pojawiającego się często z powołaniem na Emmanuela Levinasa zaimka „inny”. Poza wielkimi narracjami (pojęcie grand narrative) tłumaczone są rozliczne pojęcia semiotyczne: performatywność, diegesis narracji (fantastyczne tworzone przez literaturę i film wszechświaty), także symulakry (reprezentacje, które nic nie reprezentują - Baudrillard). Dużą frekwencję w analizowanych słownikach teorii krytycznej mają terminy wykorzystywane w psychoanalizie: nazwy mechanizmów obronnych, kompleksów, podświadomość, nieświadomość; dalej - wyprowadzane z psychoanalizy i estetyki, ważne dla rozumienia niektórych motywów współczesnej literatury i filmu: niesamowitość (uncanny) itp. W tej kategorii sytuują się na przykład: Lacanowski porządek symboliczny, fazy postrzegania siebie, fallocentryzm. Detalicznie są przedstawiane kategorie wprowadzone nomen omen w dyskurs przez Foucaulta: porządek dyskursu, bio-

Lista postaci, które zostały wybrane do prezentacji, jest długa. Nawiasem mówiąc, można omawiane pozycje odnaleźć w kilku seriach przygotowanych (przekład i publikacja) przez Wydawnictwo Krytyki Politycznej lub - rzadziej - w serii „Spectrum” wydawnictwa Muza. 
polityka, rządomyślność, reżimy prawdy, archeologia i genealogia, przywoływane przezeń znaczenia metafor, takich jak panoptikon. Dalej terminy wprowadzane przez Habermasa: sfera publiczna, działanie komunikacyjne, racjonalność komunikacyjna. Tłumaczone są także terminy socjologiczne charakterystyczne dla koncepcji Pierre'a Bourdieu: pole, habitus, przemoc symboliczna. Politycznych teorii i właściwych im znaczeń nie ma tu wiele, jeśli gdzieś jest hasło polity$\mathrm{ka}$, to w skojarzeniu politics and orginal sin i zawiera omówienie koncepcji Carla Schmitta (Payne, Barbera, 2010, s. 546), marginalnie jest przywołany w słownikowym przekazie koncept radykalnej demokracji Ernesta Laclau i Chantal Mouffe. Dużo więcej uwagi poświęcono wielokulturowości, pojęciom takim, jak kosmopolityzm czy polityczna poprawność, wspomniana wcześniej ideologia, tu jako kulturowa hegemonia, czy Althusserowskim „aparatom ideologicznym” (ISAs). Ważne też są definicje takich pojęć, jak kolonializm, rasizm, seksizm. Liczne są odwołania do feministycznych teorii ${ }^{10}$.

Specyfika zainteresowań i w pewnym sensie historia rozwoju teorii krytycznej siłą rzeczy rzutują na jej terminologię. Widoczny jest mariaż tego nurtu z Marksem oraz Freudem, myślenie w kategoriach dialektycznych, odniesienia do kanonicznej rozprawy o dialektyce oświecenia, eksponowanie kwestii kulturowych i estetycznych, związanych z formowaniem się społeczeństwa masowego. Niemniej jednak poza terminami globalizacji, glokalizacji, konsumpcjonizmu i karnawalizacji można byłoby się spodziewać nieco więcej. Lapidarnie przedstawiana jest społeczna dynamika, rewolucje, ruchy społeczne, co poniekąd jest wskaźnikiem innej ciekawości i wpływów strukturalizmu i poststrukturalizmu. Wszelkie przytoczone wyżej przykłady obrazować mogą inną cechę - przy okazji lubiany i używany termin. Teoria krytyczna ma swój trzon, pień, fundament, wielu współczesnych twórców pozostaje jednak w fazie, którą antropolog (Victor Turner) nazwałby liminalną. Znaczy to mogą być oni do teorii krytycznej zaliczani, bądź nie, mogą wyrażać akceptację dla stanowiska etycznego, związanego z perspektywą patrzenia nie tylko na historię, ale i cały świat społeczny z dołu, z pozycji klas czy grup marginalizowanych.

Kolejna cecha teorii krytycznej, dająca się wyróżnić na podstawie tego typu źródeł, odnosi się do metodologii. Selekcja przedstawianych koncepcji uprawiania nauki, wykorzystywanych metod, preferencji w tym zakresie wykazuje ukierunkowanie konstruktywistyczne, fascynację antropologią interpretatywną. Reprezentacją będzie zestaw trzech prezentowanych sylwetek - Paula K. Feyerabenda, Benedicta Andersona oraz Clifforda Geertza. Pierwszy z obrazoburczą wizją nauki, anarchizującej, rozbijającej utarte schematy, wartej jednak nieby-

10 Dodać należy, że grono intelektualistów i działaczy kojarzonych z teorią krytyczną wymieniane $\mathrm{w}$ analizowanych publikacjach jest wielce nie-parytetowe. 
wałego szacunku przez swoje kulturowe znaczenie. Drugi jako autor Wspólnot wyobrażonych, tym samym autor koncepcji, do której warto się odwoływać w eksplikacji wielu pojęć determinujących świadomość współczesnego człowieka (naród, rasa, płeć), warunkujących proces negocjacji tożsamości. Z kolei koncepcja „opisu gęstego" Geertza jest dyrektywą działania, wnikliwości, uwzględniania wszystkich kontekstów i zmiennych, sięgania wzdłuż, wszerz i w głąb.

Pozostaje jednak jeszcze jeden problem. Związek teorii z praktyką, fundamentalne dla teorii krytycznej praxis, wcielanie w życie idei. Trudno jednak dostrzec $\mathrm{w}$ konstruowanej słownikiem wizji tego paradygmatu i orbitujących wokół niego przedstawicieli intelektualnych środowisk szczególną pasję do wyjścia zza biurka lub pozamedialnego, na przykład politycznego, zaangażowania. Praktyka to jednak także dzieło literackie i sztuka - teatr, film, performance. W słownikach teorii krytycznej znajdziemy wyjaśnienie terminów, takich jak kamp, pastisz, kicz, przykłady nowatorstwa, opis kierunków sztuki - ważnych raczej w czasach pierwszej generacji szkoły frankfurckiej niż teraz. Widać umiarkowaną wagę przypisywaną reprezentantom Nowej Lewicy, choć sporo o sytuacjonistach, społeczeństwie spektaklu i innych pojęciach rozwijanych przez Guy Deborda ${ }^{11}$.

Tekst jest zawsze tajemnicą, dziełem otwartym, by przypomnieć tu jeszcze często przywoływanego przez badaczy szkoły krytycznej Umberta Eco i jego refleksje na temat możliwych polisemicznych interpretacji. Notabene w konstrukcji słowników, a przy okazji w subdyscyplinarnej terminologii kojarzonej z teorią krytyczną, ostatnie hasła są wprowadzane niejako na siłę, na przykład Zeitgeist, zeugma i żdanowszczyzna (Macey, 2000, s. 408; Buchanan, 2010, s. 499). Wielowątkowość związana z licznymi tradycjami, interdyscyplinarność, wszystkie cechy teorii krytycznej rzutują na to, że kolejni badacze lub ich zespoły podejmują działania w celu usystematyzowania podejścia, rekonstrukcji właściwej dla niej terminologii. Konkluzją może być zatem postulat przygotowania takiego leksykonu, którego zadaniem będzie wyodrębnienie znaczeń ważnych dla politologii.

\section{Literatura}

Adorno, T.W. (1984). „Socjologia i dialektyka”. W: E. Mokrzycki (wyb. i oprac.). Kryzys i schizma. Antyscjentystyczne tendencje w socjologii wspótczesnej, t. 2, przeł. D. Lachowska. Warszawa: Państwowy Instytut Wydawniczy.

Baert, P., Carreira da Silva, F. (2013). Teorie społeczne w XX wieku i dzisiaj, przeł. S. Burdziej. Kraków: Zakład Wydawniczy Nomos.

11 Autor obszernego wprowadzenia do wznawianej publikacji Guy Deborda trafnie zauważa, że jest ona znana, przywoływana i cytowana..., , ale nie w Polsce” (Kwaterko, 2016, s. 5). 
Bal, M. (2012). Wędrujące pojęcia w naukach humanistycznych. Krótki przewodnik, przeł. M. Bucholc. Warszawa: Narodowe Centrum Kultury.

Baudrillard, J. (2012). Słowa klucze, przeł. S Królak. Warszawa: Sic!

Beyme, K. von. (2005). Współczesne teorie polityczne, przeł. J. Łoziński. Warszawa: Wydawnictwo Naukowe Scholar.

Blok, Z. (1999). Teoria polityki. Studia. Poznań: Wydawnictwo Naukowe Instytutu Nauk Politycznych i Dziennikarstwa Uniwersytetu im. Adama Mickiewicza.

Buchanan, I. (2010). A Dictionary of Critical Theory. Oxford: Oxford University Press.

Buckler, S. (2006). „Teoria normatywna”. W: D. Marsh, G. Stoker (red.). Teorie i metody w naukach społecznych. Kraków: Wydawnictwo Uniwersytetu Jagiellońskiego.

Burawoy, M. (2009). „O socjologię publiczną. Przemówienie prezydenckie z roku 2004”. W: A. Manterys, J. Mucha (red.). Nowe perspektywy teorii socjologicznej. Kraków: Zakład Wydawniczy Nomos.

Elliott, A. (2011). Współczesna teoria społeczna, przeł. P. Tomanek. Warszawa: Wydawnictwo Naukowe PWN.

Felluga, D.F. (2015). Critical Theory: The Key Concepts. New York: Routledge.

Guba, E.G., Lincoln, Y.S. (2009). „Kontrowersje wokół paradygmatów, sprzeczności i wyłaniające się zbieżności”. W: N.K. Denzin, Y.S. Lincoln (red.). Metody badań jakościowych, t. 1, przeł. M. Bobako. Warszawa: Wydawnictwo Naukowe PWN.

Horkheimer, M. (1987). Społeczna funkcja filozofii. Wybór pism, przeł. J. Doktór. Warszawa: Państwowy Instytut Wydawniczy.

Jabłoński, A.W. (2011). „Pluralizm teoretyczny w politologii”. W: Z. Blok (red.). Czym jest teoria w politologii? Warszawa: Dom Wydawniczy Elipsa.

Karwat, M. (2009). „Syndromatyczny charakter przedmiotu nauki o polityce”. W: Demokratyczna Polska w globalizujacym się świecie. I Ogólnopolski Kongres Politologii, Warszawa, 22-24 września 2009 (red. nauk. K.A. Wojtaszczyk, A. Mirska). Warszawa: Wydawnictwa Akademickie i Profesjonalne.

Karwat, M. (2011). „Rodzaje teorii w nauce o polityce”. W: Z. Blok (red.). Czym jest teoria polityki? Warszawa: Dom Wydawniczy Elipsa.

Klementewicz, T. (2010). Rozumienie polityki. Zarys metodologii nauki o polityce. Warszawa: Dom Wydawniczy Elipsa.

Klementewicz, T. (2013a). „Politologia jako wieloparadygmatyczna struktura wiedzy”. Kwartalnik Naukowy OAP UW „e-Politikon”, 5, s. 164-198.

Klementewicz, T. (2013b). „Politolog w labiryncie paradygmatów - pułapki eklektyzmu”. W: B. Krauz-Mozer, P. Ścigaj (red.). Podejścia badawcze i teoretyczne w nauce o polityce. Kraków: Księgarnia Akademicka.

Krauz-Mozer, B. (2005). Teorie polityki. Założenia metodologiczne. Warszawa: Wydawnictwo Naukowe PWN.

Kristeva, J. (1982). Powers of Horror. An Essay on Abjection. New York: Columbia University Press. 
Kwaterko, M. (2016). „Wstęp i komentarz”. W: G. Debord, Społeczeństwo spektaklu oraz Rozważania o społeczeństwie spektaklu, przeł. M. Kwaterko. Warszawa: PIW.

Macey, D. (2000). Dictionary of Critical Theory. London: Penguin Reference.

Marody, M. (1987). Technologie intelektu. Językowe determinanty wiedzy potocznej i ludzkiego działania. Warszawa: PWN.

Mucha, J. (1986). Socjologia jako krytyka społeczna. Orientacja radykalna i krytyczna we współczesnej socjologii zachodniej. Warszawa: PWN.

Müller, K. Czerniak, S. (2012). „Pomiędzy socjologią a filozofią społeczną. "Walka o uznanie» Axela Honnetha”. W: A. Honneth. Walka o uznanie, przeł. J. Duraj. Kraków: Zakład Wydawniczy Nomos.

Orr, L. (1991). A Dictionary of Critical Theory. New York: Greenwood Press.

Ossowski, S. (1983). O osobliwościach nauk społecznych. Warszawa: Państwowe Wydawnictwo Naukowe.

Payne, A.M., Barbera, J.R. (eds.). (2010). Dictionary of Cultural and Critical Theory. Hoboken, NJ: John Wiley \& Sons Ltd.

Pierzchalski, F. (2017). „Politologia krytyczna - źródła i kontynuacje krytycznego paradygmatu badań w nauce o polityce”. W: M. Mikołajczyk, M. Karwat (red.). Politologii model krytyczny. Kraków: Wydawnictwo Naukowe Uniwersytetu Pedagogicznego.

Porębski, L. (2013). „Obmacując słonia, czyli czy istnieje jedna nauka o polityce”. W: Ł. Młyńczyk, B. Nitschke (red.). Aspekty metodologiczne oraz teoretyczne w subdyscyplinach politologii. Toruń: Wydawnictwo Adam Marszałek.

Szacki, J. (2007). Historia myśli socjologicznej. Warszawa: Wydawnictwo Naukowe PWN.

Szahaj, A. (2008). Teoria krytyczna szkoły frankfurckiej. Warszawa: Wydawnictwa Akademickie i Profesjonalne.

Wierzbicka, A. (2007). Słowa klucze: różne języki - różne kultury, przeł. I. Duraj-Nowosielska. Warszawa: Wydawnictwo Uniwersytetu Warszawskiego.

Wiśniewski, T.R. (2004). „Krytyka i zniesienie polityki według Teorii Krytycznej”. W: T. Klementewicz (red.). Współczesne teorie polityki - od logiki do retoryki. Studia Politologiczne, 8, s. 112-137.

Wycisk, A. (2014). „Teoria krytyczna - szkoła frankfurcka”. W: M.S. Szczepański, A. Śliz (red.). Współczesne teorie społeczne. W kręgu ujęć paradygmatycznych. Opole: Wydawnictwo Uniwersytetu Opolskiego.

\section{Streszczenie}

Przedmiotem prezentowanej analizy jest siatka pojęciowa stosowana przez badaczy identyfikowanych z paradygmatem lub teorią krytyczną. Źródłem są słowniki przedstawiające charakterystyczne dla formacji postaci, problemy i kontrowersje. Opracowania tego typu zawierają wyselekcjonowany zestaw terminów, definicje sprawozdawcze, tym samym autorskie lub 
- rzadziej - uzgodnione w obrębie dyscypliny naukowej sposoby rozumienia zjawisk społecznych. Materiały analizowane stanowią ilustrację interdyscyplinarności i wielowątkowości podejścia krytycznego. Pokazują również, jakie znaczenie ma dorobek niektórych autorów, także jeśli chodzi o kreatywność w zakresie słowotwórstwa i umiejętność eksplikacji pojęć i towarzyszących im koncepcji. Terminologie często decydują o statusie teorii naukowej. Konstrukcje pojęć są z kolei potwierdzeniem trafności obserwacji i wyobraźni społecznej. Same zaś pojęcia mogą być porównane do podejmowanych przez kolejne generacje tropów pozwalających otwierać nowe bramy i wytyczać nowe ścieżki. Termin „rizomatyczny” (rhisomatic) odniesiony do tekstów i dyskursów przez francuskich filozofów (Félix Guattari, Gilles Deleuze) może ilustrować także formowanie teorii krytycznej. Jeśli politologia miałaby korzystać z dotychczasowego dorobku krytycznych nauk społecznych, warto przyjrzeć się politycznym kontekstom dotychczasowych badań prowadzonych w tym nurcie oraz specyfice podejścia metodologicznego, w tym konstrukcji siatki pojęciowej.

Słowa kluczowe: interdyscyplinarność, teoria krytyczna, siatka pojęciowa, kluczowe problemy, tworzenie pojęć 